\title{
MARKET PARTICIPATION INTENSITY EFFECT ON PRODUCTIVITY OF SMALLHOLDER COWPEA FARMERS: EVIDENCE FROM THE NORTHERN REGION OF GHANA
}

\author{
Ebenezer KONDO
}

\author{
Address: \\ Biotechnology and Nuclear Agriculture Research Institute-Ghana Atomic Energy Commission, P.O Box LG 80, Legon- \\ Accra, Ghana. +233 242743989 \\ Email address: kondoebenezer@gmail.com
}

\begin{abstract}
This paper explored the effect of market participation intensity on productivity of smallholder cowpea producers in the Northern Region of Ghana. A cross-sectional primary data of 183 cowpea producers was sampled from three communities in each of four selected districts in the region. The Instrumental Variable (IV) regression model using the 2SLS estimator was employed to estimate the causal effect of intensity of market participation on productivity. The results revealed that market participation intensity, measured as the proportion of output sold is endogenous in the cowpea on-farm productivity model. This finding implies that policy measures that lower transaction costs will significantly boost smallholder cowpea productivity by empowering farmers to intensify their participation in the market. Additionally, policies tailored towards increasing farmers' farm size, removing barriers in accessing and cultivation of improved varieties of cowpea seed as well as diversification of agricultural production activities should be promoted. Furthermore, opportunities created to enable these farmers upgrade themselves through the formal educational system will in the long run enable them to raise their on-farm cowpea productivity level through the adoption of productivity enhancing technologies.
\end{abstract}

Keywords: productivity, intensity of market participation, cowpea, endogeneity, Ghana JEL: Q13, Q15, Q18, R53, R58

\section{INTRODUCTION}

Ghana's agriculture is smallholder dominated, with these farmers dwelling predominantly in rural communities, and close to $90 \%$ of their land holdings are less than 2 hectares in size and they are also resource poor (MoFA -SRID, 2016). Agricultural policy frameworks and strategies such as the Food and Agriculture Sector Development Policy (FASDEP I \&II), Ghana Shared Growth and Development Agenda (GSGDA) and the Medium Term Agriculture Sector Investment Plan (METASIP) have been accented to and developed by the government of Ghana with the view to spurring accelerated growth and productivity in the sector. These policies are also geared towards increased participation in the market by smallholder farmers to ensure food security (Abu, et al. 2016). Following from these policies, successive governments have thus over the years, with the support of multiple NGOs, launched various projects that stimulate agribusiness agendas and link farmers to markets (Akpalu et al. 2015; Abdulai and Huffman, 2000; MoFA, 2011). Government's current flagship agricultural programme, "Planting for Food and Jobs (PFJ)" aims at targeting interventions that dovetail into a transformative goal of intensifying the market orientation of the smallholder farming sector. The programme is therefore designed to provide farmers with marketing support and inputs, including high yielding seed varieties and targeting better transportation infrastructure in crop growing areas.

Smallholder producer's choice to intensify participation in agricultural markets is considered an essential determinants of household agricultural productivity, level of commercialisation and kind of crop diversification practised on-farm (Asfaw et al. 2012; Lipper et al. 2010; Lipper et al. 2006; Smale, 2006). In general, arguments for why intensity of participation in the market by smallholder farmers is essential to improving household productivity and wellbeing of rural dwellers have been compartmentalised into two (Barrett, 2008). The first is that, it gives farmers the leverage to concentrate on producing goods in which they are experienced in producing, and trading the generated surplus for other desirable goods and services for which they possess no such comparative advantage. The last is that, it enables them capture greater economies of scale and technology adoption which, collectively, leads to a more rapid total factor productivity growth (Asfaw et al. 2012; Barrett, 2008). Improving access to markets for smallholder farm households is a potential pathway to enhancing their productivity levels.

Akpalu et al. (2017) also emphasise the need for market participation resulting from higher land productivity and the vice versa driving the agricultural transformation agenda. This according to them has the ability to raise the incomes of subsistence, low input, low 
productivity farming systems practised by farmers in the Northern Region in particular and Ghana as a whole. To this end, boosting agricultural productivity and intensifying market participation of smallholder cowpea producers is considered the most promising strategies to achieving pro-poor growth, rural development and agricultural transformation in the Northern Region of Ghana.

The Northern Region of Ghana has been identified as one of the poorly endowed regions and the per capita income of the people fall far below the national average (Marchetta, 2011). IFAD-IFPRI (2011) and Yirzagla $\boldsymbol{e t}$ al. (2016) identify factors such as land holding size, fewer marketed crops and location for the variation in market participation intensity rates and crop production in Ghana. They further argued that production and intensity of market participation in some selected commodities such as cowpea by smallholder farmers tends to be lowest in Northern Region of Ghana. Though an agrarian region, it does not have adequate market infrastructure compared to other regions. Participation in food crop production is the dominant agricultural activity in the region accounting for $70 \%-85 \%$ of agricultural output.

Cowpea is an important food crop produced and consumed by most households in the region. It is the second most important legume crop in terms of production capacity or volume and area under cultivation after groundnut, but with higher domestic consumption levels than groundnut. MoFA-SRID (2016) and Yirzagla et al. (2016), report that average farm-level productivity on farm area basis is minimal, ranging between $0.6 \mathrm{Mt} / \mathrm{ha}$ to $1.25 \mathrm{Mt} / \mathrm{ha}$ representing an achieved yield of $50 \%$. These statistic reveal that there is the potential for yield to increase to between $1.2 \mathrm{Mt} / \mathrm{ha}$ to $2.5 \mathrm{Mt} / \mathrm{ha}$ if the appropriate production and market participation conditions are available and accessible to these smallholder producers. Mean annual production growth rates have also witnessed a declining fortune in recent years. From 2004-2009, the estimated mean annual production growth rate averaged over the six-year period was $3.62 \%$. This six-year growth rate figure however saw a sharp decline from the 2010-2015 production period to $3.77 \%$ (MoFA-SRID, 2016). With these low production volume and yield, smallholder farmers are therefore unable to obtain high marketable surpluses to enable them participate in the market, take advantage of economies of scale and increase land productivity.

Smallholder cowpea producers in the Northern Region of Ghana have not been able to out-scale production and intensified their participation in the market of the commodity which has a global market share of approximately \$1.13-2.81 billion (AATF, 2012) to improve their livelihoods. This state of affairs has arisen as a result of poor logistical infrastructure rendering the transportation of agricultural produce difficult leading to increased transaction cost in the marketing process of cowpea. The resultant effect is that smallholder farmers' ability to commercialise and intensify production have been constrained culminating in low productivity and low incomes by farmers (Abdulai and Huffman, 2000; Akpalu et al. 2015; Langyintuo et al. 2003; World Bank, 2011). That intensified market participation influences the productivity level of smallholder farmers in Ghana have not been fully and exhaustively studied and explored. It is against this backdrop of the uncertain effect of market participation intensity on productivity of smallholder cowpea farmers that this study is undertaken to contribute to the existing literature on market participation intensity linkage with productivity.

\section{DATA AND METHODS}

\section{Sampling procedure and data collection methods}

The main population for the study comprised of smallholder farmers (farmers who cultivate at most 2 ha of cowpea during the study period). All cowpea farmers who produced on more than 2 ha land holding of cowpea are excluded from the sample and therefore not considered as a smallholding. A cowpea farmer for the purpose of this study is a farmer who produces cowpea as a mono-crop or as an intercrop.

A multi-stage sampling as well as key informants interview approaches were adopted for the study. The multi-stage procedure is a three-stage; clustered, purposive and randomised sampling procedure. The three stages involve selection of the districts, communities, and lastly, selection of cowpea producers and non-producers. In the first clustering stage, four farming districts were purposively selected based on the fact that they are among the top ten cowpea producing districts in the Northern Region of Ghana. In the second stage, twelve (12) communities, three (3) from each district were selected purposively based on their production potential of cowpea. This purposive selection was done in broad discussions with district officers of MoFA. This was to prevent a random sample of communities where cowpea is not intensively produced. The third and final stage involves randomly selecting respondents from the communities chosen in the second stage. It is envisaged that identification of smallholder cowpea farmers will be difficult. Therefore, in order to overcome this challenge, a communal place (a place where farmers normally congregate as it is the case in most farming communities in the Northern Region) was used as the reference point for preparing a list of smallholder farmers. Sixty (60) cowpea producers were interviewed from the 12 communities selected in each of the four (4) districts to make up a total sample size of two hundred and forty (240). Out of this figure, one hundred and eighty-three (183) of the sampled farmers interviewed through the administration of semi-structured questionnaire were identified to intensify their participation in the market by offering some proportion of their cowpea harvest for sale.

\section{Conceptual and Analytical Frameworks}

Economists have promoted intensity of market participation as an integral part in attaining a comparative advantage in production. The fundamental argument is that smallholder farmers are able to raise their income levels by producing that which offers the highest returns to the primary factors of production namely land and labour. These smallholder farmers then use the cash or income generated to purchase household consumption items, in order not to be constrained to produce all the 
different goods required for consumption (Timmer, 1997; Govereh and Jayne, 2003) premised on their intensity of market participation. Though this concept of comparative advantage is well noted in economic theory under the assumption of frictionless markets, the reality is that the process of intensity of market participation is impeded by high transaction costs that is associated with the food marketing system (Govereh and Jayne, 2003).

Based on the concept established above, a direct synergistic relationship or linkage therefore exists between intensity of market participation and productivity of food crops, and in this case cowpea. The following potential pathway by which intensity of market participation may affect cowpea (crop) productivity can therefore be deduced: smallholder farmers' intensity of market participation in the cowpea market will enable them to acquire resources and inputs that otherwise would not be available for cowpea production and other food crop production enterprises since most smallholder farmers in the northern region of Ghana are multiple crop producers. Notably, under conditions of limited access to farm credit, smallholder farmers' ability to intensify market production may depend on their participation in cowpea production in particular and other food crop production ventures in general. For instance, Strasberg (1997), noted that under credit and input market failures in northern Mozambique, participation in cotton outgrower production ventures was the basic avenue of obtaining cash inputs for use in cotton and other food production activities. In the Central Province of Kenya, smallholders participating in coffee production obtained through their coffee co-operatives access to credit, inputs, extension services and equipment for use on coffee production as well as on other food crops. The coffee cooperatives' unambiguous support of members' food crop production activities was based on the basis that this would raise their ability to sustainably and profitably participate in coffee production, which would in turn provide longer term benefits to the company (Govereh $\boldsymbol{e t}$ al. 1999).

The analytical framework identified the factors that influenced productivity while controlling for intensity of market participation as an endogenous variable. Based on the theory of market participation, smallholders decide whether to be cowpea producers or non-producers while also deciding either to be market participants or nonmarket participants. Conditional on being a market participant, the intensity of participation or proportion of output sold is determined. This intensity of market participation is hypothesised to influence farmers' cowpea crop productivity level. From the productivity literature, factors such as household characteristics, resource endowments (private and public assets and service variables)/institutional factors, transactions costs, location variables, and market price are all hypothesised to influence productivity (Rios et al. 2009; Govereh and Jayne, 2003).

Based on insights from previous literature and economic theory, factors that affect productivity are generally composed of household characteristics, resource endowments (defined as private and public assets and service variables)/institutional factors, transactions costs, location variables, and market prices (Gyau et al. 2016; Rios et al. 2009; Govereh and Jayne, 2003). Household characteristics are denoted by five controlled variables, which are age, gender educational level, dependency ratio and farm size. Age is expected to have positive association with cowpea productivity. The hypothesis is that older farmers are expected to be more experienced in productivity enhancing decision making. Male smallholder farmers are perceived to have more access to productive assets such as land, labour and capital which increases their production capabilities and hence, a positive relationship is expected with productivity. Educational attainment enhances smallholder farmers' prospects of obtaining and processing market information accurately (Makhura, et al. 2001) as well as adoption of productivity enhancing techniques and thus a positive relationship is expected. These three socio-economic variables have also been identified to have a positive effect on productivity in empirical studies by (Barrett, 2008; Ouma and Abdulai, 2009; Weinberger, 2001). Dependency ratio is also expected to positively influence productivity since high availability of active labour force in the household will be channelled into supporting productivity enhancing activities. According to Olwande and Mathenge (2012), farm size may have indirect positive impacts on productivity. Larger farm size enables farmers to create marketable surpluses, surmount cash constraints in situation where land can be used as collateral for credit, and permit farmers to embrace improved technologies that increase productivity. Therefore positive relationship is expected between farm size and productivity.

Transaction costs variables are the key intensity market participation determinants which also affect productivity (Rios et al. 2009). These variables according to Key et al. (2000) are mostly not observable in survey data and are therefore represented with proxy variables hypothesised to be observable factors that represent them. Two of these variables were used as candidate instruments for intensity of market participation which is a continuous variable measured as proportion of output sold. The hypothesis is that, the only pathway through which these instrumental variables affect productivity is only through smallholder farmers' level of market participation intensity. The instrumental variables include ownership of means of transportation and proximity to all-weather good road. The plausibility of each of these instrumental variable as stated before relates to the extent to which it is associated with farmers' productivity through their market participation intensity and not any production relationship directly (Rios et al. 2009). However, distance to nearest market is expected to negatively affect productivity. The hypothesis is that, the longer the distance to the nearest market, the lesser the selling orientation of the smallholder farmer will be and hence the lower will be their productivity. Access to market information will potentially reduce the problem of information asymmetry and accelerate the rate of productivity decision making.

Resource endowment factors of production measure the wealth of smallholder farmers. Possession of productive assets (private and public assets) and services are mentioned as important factors of agricultural 
productivity (Rios et al. 2017; Schultz, 1964; Kirui, 2013). Private and public assets variables and service variables used as controlled variables in the model include total household income, labour, possession of own land by the smallholder farmer, value of owned livestock, access to credit, and access to extension services. Income obtained from trading activities influences productivity since farmers are able to overcome the problem of cash constraints and devote some of this income to the purchase of farm inputs to enhance productivity. Therefore the effect of total income on productivity is expected to be indefinite. The number of mandays (labour) expended on cowpea production activities can potentially positively raise the productivity level of farmers. The intuition here is that, farmers spend quality time in working on their farms and this ensure timely control of weed and insect pest that are likely to attack their crops. Having secured rights to land are mostly promoted as an avenue for generating incentives for farmers to invest in technologies and practices that engender land conservation and raise productivity in the long-run (Pingali and Rosegrant, 1995; Rios et al. 2009). Ownership of livestock, access to credit and extension services are all potential variables that can positively influence productivity (Minten and Barrett, 2008). It is however expected that the more visits the extension service provider pays to the farmers, the more likely the farmer would produce and increase productivity. Access to improved cowpea variety for cultivation and access to tractor for ploughing are also expected to positively influence productivity.

District market price of cowpea output is expected to positively affect smallholder farmers' productivity level as theorised by Key et al. (2000) and Alene et al. (2008). This variable measures the selling price of cowpea in the market. The lagged value of selling price was not used based on the cross-sectional nature of the dataset. Unobserved location-specific effects were controlled using the districts as dummy variables. These dummies were incorporated in the models as controlled variables to address dissimilarities in the overall disparities in economic and social conditions of the various communities. These location-specific disparities refer to infrastructure, inaccessibility, resource endowment, production potential and farming conditions across districts. The relationships the results from these dummies revealed are to be explained by the specific characteristics and attributes of each of the location following Mmbando et al. (2015). The dummy for Tolon district was used as a reference and was left out of the model to avoid the dummy variable trap. Tolon was used as the reference variable because it was identified to be the largest producer of cowpea with smallholder farmers obtaining higher level of productivity.

\section{Econometric Estimation}

Intensity of market participation is potentially endogenous in the cowpea food crop productivity model and therefore in order to overcome the problem of endogeneity, the Instrumental Variable (IV) approach using the Two-Stage Least Squares (2SLS) estimator was employed. The alternative estimation procedure was to employ the
Ordinary Least Squares (OLS). But this approach would not resolve the endogeneity problem and the estimators would be biased and inconsistent. The instrumental variable approach allows for the estimation of coefficients that are consistent and free from asymptotic bias from omitted variables as well as measurement errors (Angrist and Krueger, 2001). The foremost Economist to employ the procedure was P.G. Wright. Wright (1928) first discussed the issue in the seminal application of instrumental variables in estimating the elasticities of supply and demand for flaxseed, the source of linseed oil. Following from that, several other Economists such as Goldberger (1972), Morgan (1990) and Bowden and Turkington (1984) have all applied the instrumental variable procedure in diverse econometric analyses. According to Angrist and Krueger, (2001), if there is more than one valid instrument, the coefficient of interest can be estimated by two-stage least squares. While twostage least squares and other instrumental variables estimators are consistent and unbiased, the drawback of the approach is that it can also result in biased and inconsistent estimates if invalid or weak instruments are used and the model incorrectly specified leading to under or over identification issues. These estimation challenges were addressed in this study by conducting the DurbinWu-Hausman test statistics and the joint significance test of instruments validity. The Instrumental Variable 2SLS model can be specified as in Eq. 1 .

$Y_{i}=\alpha_{0}+\alpha_{1} X_{1 i}+\alpha_{2} \tilde{\theta}_{i}+\varepsilon_{1 i}$

$\theta_{i}=\beta_{0}+\beta_{1} X_{1 i}+\beta_{2} X_{2 i}+v_{1 i}$

Where $Y_{i}$ is productivity measured as gross value of cowpea output produced per hectare for cowpea production for smallholder farmer $i, \alpha_{0}, \alpha_{1}, \alpha_{2}, \beta_{0}, \beta_{1}, \beta_{2}$ and are unknown parameter estimates of interest, $X_{i}$ is a vector of common exogenous regressor variables hypothesised to be correlated with cowpea crop productivity, $\tilde{\theta}_{i}$ is the predicted values of proportion of output sold used to measure the intensity of market participation, $\theta_{i}$ is the intensity of market participation itself that is potentially endogenous in the productivity model, $\varepsilon_{i}$ is an error term $X_{2 i}$ is a vector of instruments for intensity of market participation and $v_{i}$ is an error term. Where the $E\left(\varepsilon_{1 i}\right)=0$ and $\operatorname{cov}\left(\varepsilon_{1 i}, v_{1 i}\right)=0$. The empirical model specification for the Instrumental Variable 2SLS estimation is stated as in Eq. 2, while table 1 presents a vivid description of the variables used in the estimation. STATA version 15 was used in analysing the data.

$$
\begin{aligned}
& \text { Productivity } \\
& =\beta_{0}+\beta_{1} \text { IMP }+\beta_{2} \text { Age }+\beta_{3} \text { Gender } \\
& +\beta_{4} \text { Depratio }+\beta_{5} \text { Educy }+\beta_{6} \text { Fsize }+\beta_{7} \text { Distmkt } \\
& +\beta_{8} \text { Ami }+\beta_{9} \text { Total_income }+\beta_{10} \text { Labour } \\
& +\beta_{11} \text { Livestock }+\beta_{12} \text { Cowvar }+\beta_{13} \text { Tracplough } \\
& +\beta_{14} \text { Credit } \\
& +\beta_{15} \text { Ext }+\beta_{16} \text { Cowpea_price }+\beta_{17} \text { Tolon }+ \\
& \beta_{18} \text { Yendi }+\beta_{19} \text { Mion }+\beta_{20} \text { Kum }+\varepsilon_{i}
\end{aligned}
$$


Table 1: Description of dependent, endogenous and explanatory variables included in the model

\begin{tabular}{|c|c|c|}
\hline Variable & \multicolumn{2}{|l|}{ Description/Measurement } \\
\hline \multicolumn{3}{|l|}{ Dependent Variable } \\
\hline Productivity & \multicolumn{2}{|c|}{ Natural log of gross value of cowpea produced per hectare, GHS/ha } \\
\hline \multicolumn{3}{|l|}{ Endogenous Variable } \\
\hline Intensity of Market Participation (IMP) & Proportion of cowpea output sold in kilograms & \\
\hline Explanatory Variables & & Sign \\
\hline \multicolumn{3}{|l|}{ Household Characteristics } \\
\hline Age & Age of respondent/Continuous variable & + \\
\hline Gender & Gender $/$ Dummy ( $1=$ Male, $0=$ Female $)$ & + \\
\hline Dependency ratio & Ratio of inactive to active labour/continuous & + \\
\hline Education & Educational level of respondent in years & + \\
\hline Farm size & Total farm size in hectares & + \\
\hline \multicolumn{3}{|l|}{ Transaction Cost Variables } \\
\hline Distance to market & Distance to nearest market in kilometres & - \\
\hline Access to market information & Access to market information/Dummy $(1=$ Yes, $0=$ No $)$ & + \\
\hline \multicolumn{3}{|c|}{ Resource Endowments/Institutional Factors } \\
\hline \multicolumn{3}{|l|}{ Private Assets } \\
\hline Total household income & $\begin{array}{l}\text { Natural log of total household farm income in Ghana } \\
\text { Cedis }\end{array}$ & $+/-$ \\
\hline Labour & Farm labour use in mandays & + \\
\hline Land ownership type & Landownership type/Dummy $(1=$ Own land, $0=$ No) & + \\
\hline Livestock & Value of owned livestock in Ghana Cedis & + \\
\hline \multicolumn{3}{|l|}{ Public Assets and Services } \\
\hline Access to improved cowpea seed & $\begin{array}{l}\text { Access to improved cowpea seed/Dummy }(1=\text { Yes, } \\
0=\mathrm{No})\end{array}$ & + \\
\hline Access to tractor for ploughing & $\begin{array}{l}\text { Access to tractor services for ploughing } \\
\text { /Dummy }(1=\text { Yes, } 0=\text { No) }\end{array}$ & + \\
\hline Access to credit & Access to credit/Dummy $(1=\mathrm{Yes}, 0=\mathrm{No})$ & + \\
\hline Access to extension services & Access to extension service/Dummy $(1=$ Yes, $0=\mathrm{No})$ & + \\
\hline \multicolumn{3}{|l|}{ Market Price } \\
\hline Selling price of cowpea & $\begin{array}{l}\text { Natural log of selling price per bowl of cowpea in Ghana } \\
\text { Cedis }\end{array}$ & + \\
\hline \multicolumn{3}{|l|}{ Location Variables } \\
\hline Tolon district & Household in Tolon/Dummy ( $1=$ Yes, $0=$ Otherwise) & $+/-$ \\
\hline Kumbungu district & Household in Kumbungu/Dummy $(1=$ Yes, $0=$ No $)$ & $+/-$ \\
\hline Mion district & Household in Mion/Dummy( $1=$ Yes, $0=$ Otherwise $)$ & $+/-$ \\
\hline Yendi district & Household in Yendi/Dummy $(1=$ Yes, $0=$ Otherwise $)$ & $+/-$ \\
\hline
\end{tabular}

\section{RESULTS AND DISCUSSION}

Factors influencing smallholder cowpea productivity Before proceeding to estimate the factors influencing smallholder cowpea productivity in the Northern Region of Ghana, I present a brief descriptive summary of the aggregated productivity levels and proportion of output sold in the markets by the sampled smallholder farmers in the four districts. The results are displayed in Table 3 below. For Tolon and Mion districts, the higher the level of productivity the greater the proportion of output sold in the markets. But the same conclusion cannot be made between Kumbungu and Yendi. Though farmers in Kumbungu had lower level of productivity than Yendi, they however had greater marketable surpluses than their counterparts from Yendi. What this means is that cowpea producers in Yendi produce more for household consumption than for sell in the markets and therefore having higher level of productivity does not necessary mean increased level of intensity of participation for cowpea farmers in Yendi.
Table 2: Cowpea productivity and proportion of output sold per sampled district

\begin{tabular}{lrrrr}
\hline District & Productivity & $\begin{array}{c}\text { Output } \\
\text { produced }\end{array}$ & $\begin{array}{c}\text { Output } \\
\text { sold }\end{array}$ & $\begin{array}{c}\text { Proportion } \\
\text { sold }\end{array}$ \\
\hline Tolon & 97132.80 & 35544 & 16977 & 47.76 \\
Kumbungu & 36142.80 & 13785 & 8058 & 58.45 \\
Mion & 51610.80 & 18699 & 12984 & 69.44 \\
Yendi & 39278.40 & 14313 & 5952 & 41.58 \\
Total & 224164.80 & 82341 & 43971 & \\
\hline
\end{tabular}

Source: Author's own computation

The Instrumental Variable 2SLS regression model was first checked for possible presence of multicollinearity. The estimated VIF value was less than the critical value of 10 (Gujarati and Porter, 2009; Shiferaw et al. 2008), confirming that multicollinearity was not a problem. The productivity model was also tested for heteroskedasticity by using the Breusch-Pagan/CookWeisberg test. The result indicated no presence of heteroskedasticity, since the calculated $\chi^{2}$ value of (1.45) was smaller than the tabulated $\chi^{2}$ value (3.84) at the 5\% 
significance level and one degree of freedom.

The overall test of possible endogeneity of (intensity of market participation) proportion of output sold in the productivity model produced a Durbin (score) $\chi^{2}(1)=$ 11.7937, $\mathrm{p}$-value $=0.0006$ and Wu-Hausman $\mathrm{F}(1,218)$ $=11.2662$, $\mathrm{p}$-value $=0.0009$ and they are both highly significant and therefore the null hypothesis that all the variables are exogenous is rejected (that is, the first-stage OLS and 2SLS estimates are not identical). This therefore implies that proportion of output sold is highly endogenous in the productivity model and therefore endogeneity needed to be controlled for in the estimation process. Additionally, the first-stage Ordinary Least Squares (OLS) regression estimates of F-statistic for joint significance of instruments is also highly significant, F (2, 218) $=144.88$, p-value $=0.0000$ and the Partial R-squared value $(0.550$ or $55 \%)$ is far greater than the critical nominal 5\% Wald test values and therefore the null hypothesis that the instruments used for intensity of market participation (possession of own means of transportation and proximity to good road network) are weak is also rejected. The Instrumental Variable 2SLS regression estimates are displayed in Table 3.

The results indicate that, proportion of harvest sold, instrumented by the intensity of market participation variables is a significant correlate of productivity while controlling for other exogenous variables. Statistically, an increase in the proportion of output sold by a kilogram per cedi of sales, causes productivity or the gross value of cowpea production per hectare to increase by approximately $72 \%$ while controlling for other significant exogenous variables or holding all other variables constant. This finding is consistent with that of Rios et al. (2009) and Strasberg et al. (1999) who identified a positive relationship between productivity and intensity of market participation.

Age of the smallholder farmer was found to be significant but rather had a decreasing or negative effect on productivity. This could be explained by the fact that, proportion of older people in the sample who might not be innovation inclined unlike the younger producers are less productive. This supports the finding of Boughton $\boldsymbol{e t}$ al. (2007) who estimated a negative coefficient for maize productivity in Mozambique. Other literatures that support a negative estimated coefficient for age are Siziba $\boldsymbol{e t} \boldsymbol{a l}$. (2011), Olwande and Mathenge (2012), Rios et al. (2009) and Reyes et al. (2012).

The educational attainment of the household head, measured as the number of years spent in school had a positive effect on productivity and statistically significant at $5 \%$. This means that a higher level of education of the smallholder farmer is associated with a higher level of productivity. This observation is consistent with the findings of Makhura et al. (2001), Enete and Igbokwe (2009), Randela et al. (2008), Southworth and Johnston (1967), Schultz (1945) and Ofori (1973) who argued that education will endow the household with better production and managerial skills which could lead to increased productivity and higher output.

Farm size had the expected significantly positive effect on cowpea productivity. The result indicates that the larger the farm size per capita, the more it allowed the smallholder farmer to raise their productivity level. This result is in line with Rios et al. (2009) who found that Tanzania and Vietnamese farmers with larger land per worker are more productive.

The value of livestock owned by a smallholder farmer was also found to have a significantly positive relationship with cowpea productivity and significant at $1 \%$. This finding suggests that cowpea farmers with diversified agricultural productions are likely to raise their productivity levels in order to maximise income from the sale of cowpea or maximise output for consumption in the unlikely event that their livestock do not attract good market or when they are not ready for sale. The result was found to be consistent with the findings by Minten and Barrett (2008) and Rios et al. (2009) who found similar relationship between livestock owned and crop productivity in Madagascar and Vietnam respectively.

Access to improved cowpea variety was also found to have the expected sign and significant at the 5\% level of significance. The result indicates that cowpea farmers who had access to cowpea variety for cultivation had approximately $40 \%$ higher level of productivity than farmers who had no access to improved cowpea variety for cultivation holding all other variables constant. The result was found to be consistent with Strasberg et al. (1999) who found similar relationship between hybrid seed cultivation per acre and food crop productivity in Kenya.

As expected, access to credit was also found to depict a positive relationship with productivity and significant at the $1 \%$ level of significance. This result indicates that for farmers who had access to credit, their productivity level is approximately $8 \%$ higher than those who had no access to credit for farming. This finding suggests that access to credit is pivotal in achieving higher productivity levels of cowpea in the Northern Region.

The prevailing district level selling price of cowpea grain was also found to possess the expected coefficient and significant at the $1 \%$ level of significance. The result indicates that for every cedi (GHS) increase in the selling price of cowpea harvest per kilogramme, farmers' level of productivity is expected to increase by approximately $8 \%$.

With regard to the location of smallholder producers, the coefficient for the variable indicating a smallholder producer located in the Mion district is statistically significant and negatively related to cowpea productivity as compared to a smallholder located in the Tolon district (reference district) showing an approximately 63\% lower level of productivity. Mion district is characterised by poor infrastructure with remote communities from a welldeveloped agricultural research station unlike Tolon where the Savannah Agricultural Research Institute (SARI) of the Council for Scientific and Industrial Research (CSIR) is located. Similarly, Kumbungu district also had a statistically significant relationship with productivity with cowpea producers in that district having about $86 \%$ level of productivity relative to Tolon. This may be due to the fact that it is relatively a new district with inadequate infrastructure that directly contributes to and promotes productivity 
Table 3: Instrumental variable 2 SLS regression estimates of productivity with endogenous intensity of market participation

\begin{tabular}{|c|c|c|}
\hline Variable & Coefficient & t-Statistics \\
\hline \multicolumn{3}{|l|}{ Intensity of Market Participation } \\
\hline Proportion of sales & $\begin{array}{l}0.717 * * \\
(0.875)\end{array}$ & 2.49 \\
\hline \multicolumn{3}{|l|}{ Household Characteristics } \\
\hline Age & $\begin{array}{l}-0.006^{*} \\
(0.005)\end{array}$ & -1.78 \\
\hline Gender & $\begin{array}{l}-0.061 \\
(0.200)\end{array}$ & -0.30 \\
\hline Dependency ratio & $\begin{array}{l}0.008 \\
(0.011)\end{array}$ & 0.67 \\
\hline Education & $\begin{array}{l}0.006 * * \\
(0.012)\end{array}$ & 2.52 \\
\hline Farm size & $\begin{array}{l}0.407 * * \\
0.210)\end{array}$ & 1.94 \\
\hline \multicolumn{3}{|l|}{ Transaction Cost Variables } \\
\hline Distance to market & $\begin{array}{l}0.009 \\
(0.014)\end{array}$ & 0.64 \\
\hline Access to market information & $\begin{array}{l}0.118 \\
(0.187)\end{array}$ & 0.63 \\
\hline \multicolumn{3}{|l|}{ Resource Endowments/Institutional Factors } \\
\hline Total household income & $\begin{array}{l}-0.183 \\
(0.199)\end{array}$ & -0.92 \\
\hline Labour & $\begin{array}{l}-0.013 \\
(0.012)\end{array}$ & -1.06 \\
\hline Value of livestock owned & $\begin{array}{l}0.001 * * * \\
(0.000)\end{array}$ & 3.92 \\
\hline Access to improved cowpea seed & $\begin{array}{l}0.407 * * \\
(0.210)\end{array}$ & 1.95 \\
\hline Access to tractor services for ploughing & $\begin{array}{l}0.037 \\
(0.132)\end{array}$ & 0.28 \\
\hline Access to credit & $\begin{array}{l}0.078 * * * \\
(0.026)\end{array}$ & 2.95 \\
\hline Access to extension services & $\begin{array}{l}0.010 \\
(0.119)\end{array}$ & 0.08 \\
\hline \multicolumn{3}{|l|}{ Market Price Variable } \\
\hline Selling price of cowpea & $\begin{array}{l}0.078 * * \\
(0.026)\end{array}$ & 2.95 \\
\hline Tolon district & reference & \\
\hline Yendi district & $\begin{array}{l}-0.493 \\
(0.423)\end{array}$ & -1.16 \\
\hline Mion district & $\begin{array}{l}-0.626 * * * \\
(0.167)\end{array}$ & -3.74 \\
\hline Kumbungu district & $\begin{array}{l}-0.857 * * * \\
(0.292)\end{array}$ & -2.94 \\
\hline Constant & $\begin{array}{l}3.745^{* * * *} \\
(0.859)\end{array}$ & 4.36 \\
\hline $\begin{array}{l}\text { Breusch-Pagan / Cook-Weisberg test for het } \\
\chi^{2}(1)=0.12 \\
\text { Prob }>\chi^{2}=0.7250\end{array}$ & roscedasticity & \\
\hline
\end{tabular}

Source: Author's own computation

Notes: Robust standard error in parentheses. $*$, ** and $* * *$ represent significance at $10 \%, 5 \%$, and $1 \%$ level, respectively. Dependent variable is the natural log of gross value of output produced per hectare.

\section{CONCLUSIONS}

Though cowpea is a food security crop in Ghana, land productivity has been low in the Northern Region of the country which happens to be the highest producer of the commodity. To address this low productivity phenomenon among smallholder cowpea producers, conducive marketing environment needed to be created to enable smallholder farmers intensify their market participation activities. This study examined the factors that affect productivity of cowpea while controlling for the endogeneity of intensity of market participation in the 
estimation process. The appropriate estimation tests were performed to ensure that the assumptions underlying the instrumental variable regression using the Two-Stage Least Squares estimator employed for the analysis are satisfied. The empirical results confirm the endogeneity of intensity of market participation and was therefore instrumented. Other significant exogenous variables that influence productivity of cowpea include educational level of the smallholder farmer, farm size cultivated, value of livestock owned and access to and cultivation of improved cowpea seed. Formulation of policies to ensure lower transaction costs among smallholder farmers will intensify their market participation activities and hence accelerate the promotion of pro-poor growth among smallholder cowpea producers in the Northern Region of Ghana since this will affect their productivity directly and result in higher incomes. Productivity promoting policies should also be designed to encompass formal educational training for farmers, easy access to inputs, as well as agricultural diversification.

\section{REFERENCES}

ABDULAI, A. and HUFFMAN, W. (2000). Structural adjustment and economic efficiency of rice farmers in northern Ghana. Economic Development and Cultural Change, 48(3), p. 503-520. DOI: $10.1086 / 452608$.

ABU, B.M., ISSAHAKU, H. and NKEGBE, P.K. (2016). Farmgate versus market centre sales: a multi-crop approach. Agricultural and Food Economics, 4(21). DOI: https://doi.org/10.1186/s40100-016-0065-6.

AFRICAN AGRICULTURAL TECHNOLOGY FOUNDATION. (AATF, 2012). Policy brief on potentials and constraints of cowpea for food and poverty alleviation. AATF, Nairobi, Kenya. DOI: https://www.aatf-

africa.org/files/files/publications/Cowpea\%20brief.pdf. AKPALU, W., DIAS, P. and MBIZULE, C. (2015). Improving smallholder farmer yield through guaranteed market: The case of purchase for progress (P4P) in Ghana. In AKPALU, W., MATSHE, I. and SENBET, L.W. (Eds). Linking smallholder farming to markets: Impact of purchase for progress report. Nairobi University Press, Kenya.

AKPALU, W., MATSHE, I. and SENBET, L.W. (2017). Effect of large-scale procurement on smallholders: An overview. In AKPALU, W., MATSHE, I. and SENBET, L.W. (Eds). Linking smallholder farming to markets: Impact of purchase for progress report. Nairobi University Press, Kenya.

ALENE, A.D., MANYONG, V.M., OMANYA, G., MIGNOUNA, H.D., BOKANGA, M. \& ODHIAMBO, G. (2008). Smallholder market participation under transactions costs: Maize supply and fertilizer demand in Kenya. Food Policy, 33(4), p. 318-328. DOI: https://doi.org/10.1016/j.foodpol.2007.12.001

ANGRIST, J.D. and KRUEGER, A.B. (2001). Instrumental Variables and the Search for Identification: From Supply and Demand to Natural Experiments. Journal of Economic Perspectives, 15(4), p. 69-85. DOI: $\underline{10.1257 / \text { jep. } 15.4 .69}$

ASFAW, S., LIPPER, L., DALTON, J.T. and AUDI, P.
(2012). Market participation, on-farm crop diversity and household welfare: micro-evidence from Kenya. Environment and Development Economics 17, p. 579-601. Cambridge University Press. DOI: https://doi.org/10.1017/S1355770X12000277.

BARRETT, C.B. (2008). Smallholder Market Participation: Concepts and Evidence from Eastern and Southern Africa. Food Policy, 33, p. 299 - 317. DOI: https://doi.org/10.1016/j.foodpol.2007.10.005.

BOUGHTON, D., MATHER, D., BARRETT, C. B., BENFICA, R., ABDULA, D., TSCHIRLEY, D. and CUNGUARA, B. (2007). Market Participation by Rural Households in a Low-Income Country: An Asset-Based Approach Applied to Mozambique. Faith and Economics, 50 (Fall 2007), p. 64-101.

BOWDEN, R. J. and TURKINGTON, D.A. (1984). Instrumental Variables. Cambridge: Cambridge University Press.

ENETE, A. A. and IGBOKWE, E. M. (2009). Cassava Market Participation Decisions of Producing Households in Africa. Tropicultura, 27(3), p. 129 - 136. DOI: http://www.tropicultura.org/text/v27n3/129.pdf.

GOLDBERGER, A. S. (1972). Structural Equation Methods in the Social Sciences. Econometrica. 40(6), p. 979-1001. DOI: DOI: $10.2307 / 1913851$

GOVEREH, J. and JAYNE, T.S. (2003). Cash cropping and food crop productivity: synergies or trade-offs? Agricultural Economics, 28, p. 39-50. DOI: 10.1111/j.1574-0862.2003.tb00133.x.

GOVEREH, J., NYORO, J., and JAYNE, T. (1999). Smallholder Commercialisation, Interlinked Markets, and Food Crop Productivity: Cross Country Evidence from eastern and southern Africa. Paper Presented at the Fourth Agricultural Transformation Workshop, Nairobi, Kenya. USAID/Africa Bureau/Sustainable Development Division, Washington, $D C$.

GUJARATI, D.N. and PORTER, D.C. (2009). Basic Econometrics. 5th edition, McGraw-Hill/Irwin, New York.

GYAU, A., MBUGUA, M and ODUOL, J. (2016). Determinants of participation and intensity of participation in collective action: evidence from smallholder avocado farmers in Kenya. Journal on Chain and Network Science, 16(2), p. 147-156. DOI: https://doi.org/10.3920/JCNS2015.0011.

IFAD-IFPRI. (2011). Agricultural commercialization in northern Ghana. Innovative Policies on Increasing Access to markets for High-Value Commodities and Climate Change Mitigation. IFAD-IFPRI Partnership Newsletter. https://ifadifpri.files.wordpress.com/2010/08/ifad-ifpri-

newsletter-market-access-may-2011.pdf.

KEY, N., SADOULET, E. and DE JANVRY, A. (2000). Transaction Costs and Agricultural Household Supply Response. American Journal of Agricultural Economics 82 , p. 245-59. DOI: https://doi.org/10.1111/00029092.00022.

KIRUI, O.K. (2013). Drivers of collective action and the welfare gains of such initiatives among smallholder farmers: experiences from Kenya. Paper prepared for the 4th Conference of AAAE. September 22-25, 2013. Hammamet, Tunisia. 
LANGYINTUO, A.S., LOWENBERG-DEBOER, J., FAYE, M., LAMBERT, D., IBRO, G., MOUSSA, B. KERGNA, A. KUSHWAHA, S., MUSA, S. and NTOUKAM, G. (2003). Cowpea Supply and Demand in West and Central Africa. Field Crops Research, 82, p. 215 231. DOI: https://doi.org/10.1016/S03784290(03)00039-X.

LIPPER, L., ANDERSON, C.L., and DALTON, T.J. (Eds). (2010). Seed Trade in Rural Markets: Implications for Crop Diversity and Agricultural Development, Rome: FAO and London: Earthscan

LIPPER, L., CAVATASSI, R. and WINTERS, P. (2006). Seed supply and the on-farm demand for diversity: a case study from Eastern Ethiopia, in M. SMALE (Ed.), Valuing Crop Biodiversity: On Farm Genetic Resources and Economic Change, Wallingford: CABI Publishing, p. 223 -250 .

MAKHURA, M., KIRSTEN, J. and DELGADO, C. (2001). Transaction costs and smallholder participation in the maize market in the Northern Province of South Africa. Seventh Eastern and Southern Africa Regional Maize Conference, 11-15 February, Pretoria, South Africa.

MARCHETTA, F. (2011). On the Move: Livelihood Strategies in Northern Ghana. Post-Doctorante CNRS, Clermont Universite, France. https://halshs.archivesouvertes.fr/halshs-00591137.

MMBANDO, F. E., WALE, E. Z. and BAIYEGUNHI, L. J. S. (2015). Determinants of smallholder farmers' participation in maize and pigeonpea markets in Tanzania. Agrekon, 54(1), p. 96-119. DOI: https://doi.org/10.1080/03031853.2014.974630

MINTEN, B. and BARRETT, C.B. (2008). Agricultural technology, productivity and poverty in Madagascar. World Development, 36(5), p. 797-822. DOI: https://doi.org/10.1016/j.worlddev.2007.05.004.

MINISTRY OF FOOD AND AGRICULTURE (MOFA, 2011). Agriculture in Ghana. Facts and figures (2010). Statistics, Research and Information Directorate (SRID). Accra, Ghana. www.mofa.gov.gh.

MINISTRY OF FOOD AND AGRICULTURESTATISTICS, RESEARCH AND INFORMATION DIRECTORATE. (MOFA-SRID, 2016). Agriculture in Ghana: Facts and Figures 2015, Accra-Ghana. www.mofa.gov.gh.

MORGAN, M. S. (1990). The History of Econometric Ideas. Cambridge: Cambridge University Press.

OFORI, I. M. (1973). Factors of Agricultural Growth in West Africa. ISSER, University of Ghana, Legon, Accra, Ghana.

OLWANDE, J. and MATHENGE, M. (2012). Market Participation among Poor Rural Households in Kenya. In Paper Presented at the International Association of Agricultural Economists Triennial Conference, Brazil. (18-24

August).

https://ageconsearch.umn.edu/bitstream/126711/1/Olwan de.pdf.

$\overline{\text { OUMA }}$, E. and ABDULAI, A. (2009). Contributions of social capital theory in predicting collective action behavior among livestock keeping communities in Kenya. International Association of Agricultural Economists Conference. August 16-22, 2009. Beijing, China.
https://ageconsearch.umn.edu/bitstream/49994/2/Manusc ript $\% 20$ No. $\% 20423$ Social\%20capital\%20theory\%20an d\%20collective\%20action.pdf

PINGALI, P.L. and ROSEGRANT, M.W. (1995). Agricultural Commercialization and Diversification: Processes and Policies, Food Policy, 20(3), p.171-85. DOI: https://doi.org/10.1016/0306-9192(95)00012-4

RANDELA, R., ALEMU, Z. G. and GROENEWALD, J. A. (2008). Factors enhancing market participation by small-scale cotton farmers. Agrekon, 47(4), p. 451-469. DOI: https://doi.org/10.1080/03031853.2008.9523810.

REYES, B., DONOVAN, C., BERNSTEN, R. and MAREDIA, M. (2012). Market participation and sale of potatoes by smallholder farmers in the central highlands of Angola: A Double Hurdle Approach. In Selected Paper prepared for presentation at the International Association of Agricultural Economists (IAAE) Triennial Conference, Brazil. (18-24 August).

https://pdfs.semanticscholar.org/6d43/39f27a8b7974a8fe 736b6e49d08dc2a669d7.pdf.

RIOS, R.A., SHIVELY, G.E. and MASTERS, W.A. (2009). Farm productivity and market participation: Evidence from LSMS Data: Paper presented at the International Association of Agricultural Economics Conference, Beijing, China, (August 16-22). https://ageconsearch.umn.edu/bitstream/51031/2/RSM R eference43.pdf.

SCHULTZ, T.W. (1964). Transforming Traditional Agriculture. (1983 ed). Chicago: University of Chicago Press

SCHULTZ, T. W. (1945). Agriculture in an unstable Economy. McGraw-Hill Book Company Inc., New York. SHIFERAW, B.A., KEBEDE, T.A. and YOU, L. (2008). Technology adoption under seed access constraints and the economic impacts of improved pigeonpea varieties in Tanzania. Agricultural Economics, 39 (3), p. 309-323. DOI: https://doi.org/10.1111/j.1574-0862.2008.00335.x SIZIBA, S., KEFASI, N., DIAGNE, A., FATUNBI, A.O. and ADEKUNLE, A.A. (2011). Determinants of cereal market participation by sub-Saharan Africa smallholder farmer. Learning Publics Journal of Agriculture and Environmental studies, 2(1), p. 80-193. https://www.researchgate.net/publication/216365595_De terminants_of cereal_market_participation by subSaharan Africa smallholder farmers.

SMALE, M. (ed.) (2006). Valuing Crop Biodiversity: On Farm Genetic Resources and Economic Change, Wallingford: CABI Publishing. https://www.bioversityinternational.org/e-

library/publications/detail/valuing-crop-biodiversityon-

farm-genetic-resources-and-economic-change/.

SOUTHWORTH, H. M. and JOHNSTON, B. F. (1967). Agricultural Development and Economic Growth. Cornell University Press, U.K. https://www.cabdirect.org/cabdirect/abstract/1968180112 8.

STRASBERG, P.J. (1997). Smallholder Cash-Cropping, Food-Cropping and Food Security in Northern Mozambique. Unpublished PhD Dissertation, Michigan State University, East Lansing. https://ideas.repec.org/p/ags/midips/11346.html

STRASBERG, P.J., JAYNE, T.S., YAMANO, T., 
NYORO, J., KARANJA, D. and STRAUSS, J. (1999). Effects of Agricultural Commercialization on Food Crop Input Use and Productivity in Kenya. MSU International Development Working Paper No.71, Michigan State University.

http://ageconsearch.umn.edu/bitstream/54675/2/idwp71.p df.

TIMMER, C.P. (1997). Farmers and markets: the political economy of new paradigms. American Journal of Agricultural Economics, 79, p. 621-627. DOI: https://doi.org/10.2307/1244161

WEINBERGER, K. (2001). What role does bargaining power play in participation of women? A case study of rural Pakistan. Journal of Entrepreneurship, 10, p. 209221. DOI: https://doi.org/10.1177/097135570101000205
WORLD BANK. (2011). Logistics Performance Index, 2011. World Bank. Washington, DC, USA

WRIGHT, P. G. (1928). The Tariff on Animal and Vegetable Oils. New York: MacMillan

YIRZAGLA, J., ATOKPLE, I.D.K., HARUNA, M., KUSI, F., SUGURI, I. and MUNTARI, A. (2016). Scaling out Cowpea Production in Northern Ghana: Community Seed Production Scheme. Pan African Grain Legume and World Cowpea Conference, Livingstone, Zambia. http://gl2016conf.iita.org/wp-

content/uploads/2016/03/Scaling-out-Cowpea-

Production-in-Northern-Ghana-Community-Seed-

Production-Scheme-J-Yirzagla-et-al. pdf. 